Paulo Afonso de André 1

Alfésio Luis Ferreira Braga 1

Chin An Lin 1

Gl eice Margarete de Souza Concei ção 1

Luiz Alberto Amador Pereira 1

Simone Georges El Khouri Miraglia 1

György Miklos Böhm 1

\section{Environmental epidemiology applied to urban atmospheric pollution: a contribution from the Experimental Air Pollution Laboratory (LPAE)}

\author{
Epidemiologia ambiental aplicada à poluição \\ atmosférica urbana: uma contribuição \\ do Laboratório de Poluição Atmosférica \\ Experimental (LPAE)
}

\footnotetext{
1 Laboratory of

Experimental Air Pollution

Medical School, University of São Paulo. Av. Doutor Arnaldo 455, São Paulo, SP 01246-903, Brazil. pandre@osite.com.br abraga@hsph.harvard.edu calin@uol.com.br gleice@usp.br luiz@im05.fm.usp.br miraglia@zaz.com.br gyorbohm@usp.br
}

\begin{abstract}
Systematic investigation on the effects of human exposure to envi ronmental pollution using scientific methodology only began in the 20th century as a consequence of several environmental accidents followed by an unexpected mortality increase above expected mortality and as a result of observational epidemiological and toxicological studies conducted on animals in developed countries. This article reports the experience of the Experimental Air Pollution Laboratory at the School of Medicine, University of São Paulo, concerning the respiratory system and pathophysiological mechanisms involved in responses to exposure to pollution using toxicological and experimental procedures, complemented by observational epidemi ol ogical studies conducted in the city of São Paulo. It also describes these epidemiological studies, pointing out that air pollution is harmful to public health, not only among susceptible groups but also in the general population, even when the concentration of pollutants is bel ow thelimits set by environmental legislation. The study provides valuable information to support the political and economic decision-making processes aimed at preserving the envi ronment and enhancing quality of life. Key words Cohort Studies; Case-Control Studies; Air Pollution; Environmental Pollution
\end{abstract}

Resumo A investi gação sobre os efeitos da exposi ção humana à pol uição ambi ental iniciou de manei ra sistemática, com abordagem científica, apenas no século $X X$, como conseqüência de uma série de aci dentes ambi entais percebi dos por um si gnificativo aumento na mortalidadee com a realização de estudos epi demiológi cos observacionais e toxicológi cos em ani mais. Tais estudos têm se concentrado nos países consi derados desenvolvidos. Este arti go relata a experiência do Laboratório de Polui ção Atmosférica Experimental (LPAE), da Faculdade de Medicina da Universi dade de São Paulo, no estudo dos mecani smos fi siopatológi cos do si stema respi ratório em face da exposi ção aos poluentes, utilizando abordagens experimentais e toxicológicas, complementadas com estudos epi demi ol ógi cos observaci onais na ci dade de São Paulo. Descreve como esses estudos se inserem no panorama mundial, convergindo para um consenso de que a poluição do ar é prejudicial à saúde pública, e que esses efeitos são observados inclusi ve em concentrações de poluentes abaixo dos limites estabel eci dos pela legisl ação ambi ental em vi gor, fornecendo dados valiosos para subsi diar a tomada de deci sões políticas e econômi cas para a meIhoria do meio ambiente.

Palavras-chave Estudos de Coortes; Estudos de Casos e Controles; Polui ção do Ar; Polui ção Ambiental 
Introduction

London, December 1952. Mr. Smith with dyspnea, cough, expectoration, and fever of $38^{\circ} \mathrm{C}$, came to the St. Thomas Hospital and met a crowd with approximately the same symptoms in the emergency room. He was admitted to the hospital for treatment. A few days later this 60-year-old man died.

São Paulo, June 1991. Sílvia, 2 years old, was brought by her mother to the Pediatrics Institute at the University Hospital in São Paulo with dyspnea, cough, and expectoration. Medicated for acute asthma and sent home.

Although fictional, these cases were based on real situations: the first in London's worst air pollution disaster of all time, in 1952, during the winter when a thermal inversion prevented the dispersion of air pollutants, with an admixture resulting from coal and diesel burned with an extremely high sulfur content. Combined with the traditional London fog, they produced an acid aerosol causing most of the mortality (Logan, 1953). The second, in São Paulo, was based on the experience of the Pediatrics Institute's emergency room attendance during a winter period with pollutant concentrations slightly above currently accepted thresholds (Farhat, 1999; Lin, 1999). In both situations, epidemiological analysis was required to demonstrate the association between air pollutants and the increase in morbidity and mortality.

During the 40 years between these two episodes, epidemiological techniques have made great strides in evaluating the impact of air pollution. This review is intended to describe such techniques, based on our experience.

The systematic and scientific investigation of air pollution only began in the 20th century as a result of a series of environmental accidents, with a significant observed increase over the expected mortality rate (Firket, 1931; Logan, 1953; Ciocco \& Thompson, 1961). In addition to epidemiological research, toxicological studies on animals were also conducted. Despite much discussion about their validity and contradictory results, we contend that the two types of research are useful and complementary.

From a geopolitical perspective, most research has been conducted in developed countries, not only because they have the funds and research facilities to conduct it, but also because they enjoy a favorable political and social environment that places value on human beings (Elson, 1987; WHO, 1996a).

\section{Toxicological studies}

The Experimental Air Pollution Laboratory (LPAE) was established in 1979 with toxicological studies on the effects of motor vehicle fuels (gasoline and ethanol) on laboratory animals, and mainly on their respiratory systems. Brazil had recently launched the world's largest alternative fuel program, using non-fossil power sources, so that such research was highly relevant. Experiments were performed in intoxication chambers, and the main finding was alcohol's lower toxicity as compared to fossil fuels (Böhm et al., 1983; Massad et al., 1985, 1986). No transposition of these findings to São Paulo's human population was performed.

At the time, $90 \%$ of São Paulo's air pollution was produced by motor vehicles (CETESB, 1996) and already posed a serious health problem. There are now 5 million vehicles, and since no improvements have been made in the public transportation, the threat of pollution to the population is on the rise.

In addition, according to an ecological study by Miraglia et al. (1997), interruption of ethanol use as an alternative fuel is concentrating the urban transportation energy matrix exclusively on fossil compounds, dramatically aggravating the air pollution scenario in the city of São Paulo and causing an increase of $13 \%$ in mortality due to respiratory diseases in the population over 65 years.

The effects of urban air pollution present some complex and specific local characteristics, stemming not only from the specific sources of pollutants (industrial and economic activities, type of fuel used, urban traffic, etc.) but also from conditions for their dispersion. It is important to recognize the various cycles of concentration-dispersion: day and night, weekly and yearly variations, etc. (Schwartz, 1994b; WHO, 1996a).

Atmospheric dispersion depends on the pollutants' own characteristics, how they are emitted into the environment (vehicle exhaust, high or low smokestacks, etc.), meteorological conditions (wind direction and speed, rain, thermal inversions), and local topographic characteristics. During the dispersion process, in addition to dilution, pollutants can also change as a result of their chemical reactivity. Particulate matter may be removed from the air by deposition (due either to gravity or rainwash) or interception by plants or other obstacles (WHO, 1996a). Such factors in the city of São Paulo produce a highly complex, hazardous, and alarming scenario, especially during the winter and thermal inversions. 
The main substances identified and measured by the local environmental agency (CETESB - Companhia de Tecnologia de Saneamento Ambiental) are: sulfur dioxide $\left(\mathrm{SO}_{2}\right)$, $\mathrm{ni}-$ trogen oxides $\left(\mathrm{NO}_{\mathrm{x}}\right)$, carbon monoxide and dioxide $\left(\mathrm{CO}\right.$ and $\left.\mathrm{CO}_{2}\right)$, ozone $\left(\mathrm{O}_{3}\right)$, lead $(\mathrm{Pb})$, and total suspended particulate (TSP), of which inhalable particles $\leq 10 \mu \mathrm{m}\left(\mathrm{PM}_{10}\right)$ are of the greatest concern. Measuring and recording pollutant concentrations are extremely important components of envi ronment epidemiological research, and discontinuous measurements due to equipment malfunctioning is the most frequent problem affecting data base quality.

The LPAE first investigated responses by the respiratory system to pollution exposure in inhalation chambers with diluted car exhaust fumes. It later analyzed the respiratory functions of animals exposed to São Paulo's air pollution and compared them to control groups kept in a clean-air environment. The resulting data led us to conclude that pollution exposure could result in several hazardous health effects, such as bronchitis, emphysema, asthma, and even cancer (Böhm et al., 1989; Saldiva et al., 1992; Pereira et al., 1995; Reymão et al., 1997).

A new line of research on the effects of pollution on health has been developed at the LPAE using Tradescantia sp. plants, since their cellular kernel is able to mutate in a dose-responsive way when exposed to high concentrations of pollutants (Batal ha et al., 1999). Relevant to this point are the reviews by Saldiva $\&$ Böhm (1998) and Grant (1998) on animal and plant indicators of adverse effects associated with air pollution.

\section{Epidemiological studies}

Epidemiological studies have played an important role in understanding the effects of air pollutants in all types of indoor and outdoor environments. Despite major technical and methodological advances in recent decades, there are limitations in herent to epidemiological studies:

- they depict past events, when damage has already been done;

- exposure evaluations are subject to criticism, especially those of cumulative doses (chronic exposure);

- they generally suffer from financial limitations (prospective cohort studies) and/or methodological problems (follow-up in cohort studies and quality information in both casecontrol and ecological studies);
- they require significant samples, not always accessible in studies on human beings;

- ethical limitations may constrain the acquisition of important data, since many invasive procedures are not allowed in human beings.

Causal inference, a crucial point in epidemiological studies, has been the target of numerous attempts to ensure a reliable way of linking exposure to health effects. This problem has increased since the first populationbased studies were used in environmental and occupational health. The need to distinguish between causal and non-causal explanation led researchers to define a set of causal criteria which, once satisfied, could assure the validity of results. During the 1960s, Sir Austin Hill (1965) proposed the following set of criteria:

- strength of the association: strong associations, which remain statistically significant even after controlling for confounders, are more likely to be causal;

- consistency: similar results being observed by different researchers in different populations and under different circumstances (in the case of air environmental epidemiology, results from LPAE are analogous to those found in different places around the world);

- specificity: a cause must be associated with a single disease or group of diseases. Air pollution is associated with respiratory diseases (however, air pollutants have also been associated with cardiovascular and ophthalmic diseases);

- temporality: exposure must precede the disease to reinforce causal inference;

- biological gradient: the presence of a dosedependent association between exposure and effect, with higher exposures leading to greater effects;

- biological plausibility: based on previous knowledge about both the pathophysiology of the disease and the mechanisms by which pollutants could lead to adverse health effects. Toxicological studies in animals have helped to understand many of these processes;

- coherence: means that a causal relationship cannot conflict with the natural history of the disease, although apparently conflicting information does not invalidate a causal inference; - experimental evidence: once the association is shown, an intervention that removes the cause should attenuate or eliminate the observed effect. An episode in Utah reported by Pope III (1989) is an excellent example. A strike closed an old steel mill, which was the main source of particulate pollutants. During that period, both particulate matter levels and pediatric hospital admissions were reduced by half; 
- analogy judgment: if environmental pollutants in experimental studies prove capable of inducing both inflammatory and immunological alterations on the respiratory tract of animals (Hatch et al., 1985; Saldiva et al., 1992; Gilmour \& Selgrade, 1993; Devlin et al., 1994; Lemos et al., 1994), they may induce similar alterations in human beings.

The increasing importance of such studies and the need for global involvement in the issue led the World Health Organization, the United Nations Environmental Program, and the United States Environmental Agency to develop the Health and Environment Analysis for Decision Making, the so-called HEADLAMP project. This project initially took into account the studies conducted in Accra (Ghana) and São Paulo (Brazil), assessing the quality and availability of data which could be used to investigate possible associations between environmental exposure and health. Based on both this and other acquired experience, a preliminary version of the study was published in 1994, summarizing and indicating more appropriate methodologies in terms of study design, data collection and analysis, and inference. The guide was tested in developing countries and the results published in a final version in 1996 (WHO, 1996a, 1996b). Devised to provide the necessary information for development of public environmental polices, estimating possible impacts on health from exposure to different environmental pollutants, this guide combines methodologies from such fields as epidemiology, toxicology, and related sciences, demonstrating how to convert existing data into useful information for such estimates.

One fascinating aspect of this project is that, based on knowledge about the health effects of environmental agents described previously, it allows one to establish adequate health indicators for studies in areas with no previous research experience. It also explains how to upgrade these indicators, based on data that have generally been collected for other purposes (secondary data), in order to investigate and quantify possible associations between exposure and health effects. In a subsequent step, it allows one to interpret the results properly, thus reliably reflecting the situation in the community under study.

One of the main aims of the HEADLAMP project is to generate sufficient knowledge to support low-cost, high-quality decision-making. Quick and effective measures may thus be taken, leading to a positive impact on sustainable growth around the planet, recalling that sustainability is defined as the search for both growth and development without risks to the survival of humanity.

A historical analysis of environmental epidemiological research al ready conducted allows one to identify the most frequently used methods: ecological, cohort, and to a lesser extent case-control approaches.

\section{Ecological studies}

Population-based studies have been used in environmental epidemiology since events in Meuse Valley, Belgium (Firket, 1931), Donora, United States (Ciocco \& Thompson, 1961), and London, England (Logan, 1953). Such “ecological" or "aggregate" approaches use groups rather than individuals as units of observation (Morgenstern, 1995). Thus, the joint distribution of any combination of variables at the individual level (exposed cases, exposed noncases, unexposed cases, and unexposed noncases) is unknown (Fletcher et al., 1996). The analysis generally uses secondary data, like the number of deaths, hospital admissions, emergence room visits, symptoms of specific diseases, or variation in medication on a daily, weekly, or monthly basis.

An ecological study may be classified first according to the method used to measure exposure. It is called exploratory if there is no exposure of interest (or it was not measured) and the target of the study is to define the disease behavior (variable of interest), looking for a seasonal and/or spatial profile; it is analytical if the exposure is measured and included in the analysis and the aim is to investigate a possible correlation between exposure and morbid effect. It may seem strange to pursue causal inference in ecological studies (the purists might say it is inconsistent or absurd). However, developments in the areas of study design and statistical tools to analyze time series have led researchers to make strong assertions about causal ity in the air pollutant/ disease relationship. An association found in an ecological study that proves to be robust, consistent, specific, temporally ordered, with both gradient and biological plausibility, coherent, and experimentally proven according to the criteria proposed by Sir Austin B. Hill may be assumed as causal (Schwartz, 1994a).

A second way of classifying epidemiological studies considers the method of grouping data (Morgenstern, 1995). In this case it may be identified by:

- place (multiple-group study), where disease rates are compared among many regions; 
- time (time-trend study or time-series study), where disease rates are compared over time in one geographically determined population. This form is less susceptible to errors than multiple-group studies;

- place and time (mixed study), where rates are compared among many regions over time. Several reasons have been cited for the use of ecological studies. To mention a few:

- low cost and short time frame, since secondary data have al ready been collected and can easily be arranged. Such is the case of morbidity and mortality data and air pollutant measurements;

- adjustment to situations where working with individual measurements would be inadequate or too expensive;

- interest in ecological effects, when population interventions, such as educational programs, new laws, or public polices have been evaluated.

Simplicity of both analysis and presentation were consi dered inherent advantages of ecological studies until a decade ago. Some methodological problems are worth mentioning:

- it is sometimes impossible to directly estimate risk that a given event will occur, because the real distribution inside the group is unknown;

- individual exposure measures cannot be used to estimate group exposure, since variability in the group's exposure is unknown;

- if mean values are adopted for exposure, disease, and other covariates, their adequacy for estimating individual exposure is inversely proportional to the size of the area studied.

However, when the intent is to study the association between variability in both exposure and disease, the ecological approach is the most appropriate, whether in multiple-group studies, where external migration may induce bias in the group comparison, or in time-series studies, where the influence of confounders must be controlled. In our experience, seasonal variations and weather have shown a remarkable impact on air pollutants and health indicators.

A primordial aspect that must be analyzed is the latency period between exposure and outcome. It seems reasonable to admit that induction of adverse effects takes some time, ranging from hours to days, according to the different agents and outcomes.

In individually based epidemiological studies, variables such as smoking, alcohol consumption, housing conditions, and preexisting diseases are commonly controlled. However, ecological studies do not control such vari- ables, because the frequency in their variation is quite different from the pollution frequency being studied (Schwartz, 1994b).

Development of statistical techniques for ecological studies made it possible to control confounders, using linear and non-linear approaches, and more reliable associations between exposure and health have been shown.

An accurate population-based study demands high-quality data. These studies have been used more frequently in Europe and the United States, since they have data sets covering long periods of time and the quality of recording is excellent.

One ecological study with a major impact on the scientific community was conducted by Pope III et al. (1992). In a predominantly Mormon community, where the proportion of smokers was only around 5\%, an old steel mill was the main source of air pollutants, producing some $80 \%$ of the particulate matter in the region (particle concentration was above the air quality standard). For one year, while the plant was closed by a strike, the number of deaths due to respiratory diseases dropped significantly, comparing the periods before and after the strike. These research results helped call for a review of air quality standards.

\section{Cohort studies}

Cohort studies involve subjects from well-defined samples that can be followed for some period of time, observing:

- clinical signs and symptoms of respiratory diseases such as cough, wheezing, and frequency of medication in comparison to air pollutant levels, controlled for climatic and seasonal confounding factors.

- pulmonary function tests, recruiting individuals for a cohort study, evaluating daily pulmonary capacity tests by performing peak flow, compared to daily air pollution, temperature, and humidity data.

Time of exposure is a relevant aspect when studying the effects of air pollution. Acute episodes and chronic exposure to air pollutants should be analyzed by different methods. One can thus divide epidemiological studies into chronic and acute exposures. Cohort studies have been a kind of gold standard in environmental epidemiology, since they deal with risk from exposure to air pollution in large urban areas. They have been used sparingly due to their high cost and long-term follow-up.

Some studies using this model are considered landmarks in air pollution research. Per- 
haps the most important research has been that performed by Dockery et al. (1993), in which nearly 8 thousand individuals were followed for almost 16 years. Cardiopulmonary risk factors like smoking, alcoholism, serum cholesterol, schooling, gender, and age were monitored in 6 American cities with similar socioeconomic conditions but different average concentrations of pollutants, mainly total suspended particulate. Thestudy showed a lower life expectancy in cities with higher air pollution levels.

Both prospective cohort studies and ones like that quoted above require millions of dollars in funding, due to both the number of people involved in periodic data collection and the huge number of laboratory tests needed to control several variables in each study subject. Retrospective cohort studies, which demand less time and money, show no advantage as compared to ecological studies in terms of elucidating the relationship between air pollution and its adverse health effects. Such epidemiologists as Joel Schwartz and Douglas Dockery, from the Harvard University School of Public Health, and C. Arden Pope III, from Brigham Young University, have consistently supported this point of view.

\section{Case-control studies}

This kind of study is used for rare diseases as compared to another select control group, investigating the possible origin of exposure for that disease. The approach has been used to observe adverse events during the human reproduction process, such as fetal death and congenital abnormalities, as well as in occupational diseases like pneumoconiosis, cancer, and heavy metal poisoning (Sada-Cieslar et al., 1994; Takahashi et al., 1994; Cantor et al., 1995; Liou et al., 1997). Research comparing several types of cancer and environmental exposure with no occupational relationship also employ this method (Feychting et al., 1998; Lagarde \& Pershagen, 1999).

Quality of data and proper handling of the study are of great importance for establishing criteria for selecting groups of interest, establishing a precise diagnosis, and facilitating collection of retrospective data from these groups.

This model has been used in environmental research to evaluate possible adverse effects of air pollution on the respiratory system, especially in indoor environments, where the large number of possible biases can be controlled adequately, unlike outdoor environments.

Some advantages of this type of study (Fenster et al., 1991):
- low cost and shorter time frame as compared to alternative studies, such as prospective cohorts;

- when used to observe diseases with a short latency period (studies on fetal malformation, fetal death, acute respiratory diseases, and indoor pollution), risk of memory bias is minor.

\section{LPAE epidemiological studies}

Epidemiological studies conducted at the LPAE have basically observed the association between morbidity-mortality and air pollution in the city of São Paulo.

Mortality data in São Paulo cover an extensive time period and constitute a reliable source of information for epidemiological studies.

Data on weather and concentration of various air pollutants were collected from a network consisting of several monitoring stations from various parts of the city. Data quality varied over time because of the equipment's rapid obsolescence and lack of investment in this monitoring network administered by CETESB and the Institute of Geophysics and Astronomy (IAG).

The morbidity data in our studies were taken from a monitoring system specifically designed to administer costs in the public health system. The data's usefulness was limited, since various classes of information were inadequate or improperly classified and might thus generate confusion during analysis.

Air pollution is difficult to avoid, since the air layer surrounding the biosphere is continuous and constantly moving. Simple breathing is the most effective exposure route. The most common adverse health effects are in the respiratory and cardiovascular systems, affecting children and the elderly more frequently than other age groups.

Evidence of the acute effects of air pollution on human health was obtained by analyzing daily records on morbidity (like emergency room visits and respiratory disease admissions) and mortality (like deaths from respiratory diseases in children and the elderly). These studies suggest a dose-dependent association between air pollution and morbidity-mortality, even at concentrations below those considered safe under current environmental legislation (Saldiva et al., 1995; Miraglia et al., 1997; Pereira et al., 1998; Braga et al., 1999; Lin, 1999). Other studies (Saldiva et al., 1994, 1995) have also identified short (weekly) and long (annual) seasonal variations, as well as changes in temperature and relative humidity for both health indicators and pollutant levels. 
Several studies on the effects of air pollution on health have estimated correlations and adjustment of generalized linear models involving simple and multiple linear regression models, logistic and Poisson, besides analysis of variance (McCullagh \& Nelder, 1989; Dobson, 1990). One of the main advantages of this group of models is that they can be used in situations where the response variable follows non-normal distributions or its relationship to the explanatory variables is non-linear. The target variable is generally one of the health indicators. These represent the number of times a specific event occurs (e.g., deaths or hospital admissions) during a unit of time determined by the researcher (day, week, month, etc.). These counts generally follow Poisson distribution when it is common to use regression models involving this type of distribution. Use of this regression model also has the advantage of allowing for estimation of the relative risk, which is highly useful for evaluating the impact of pollution on the population's health (Kleinbaum et al., 1998). The Poisson regression model can be described as follows:

$\ln \left[E\left(Y_{j}\right)\right]=\sum_{j=1}^{p} X_{j} \beta_{j}$

in which In is the natural logarithm; $E\left(Y_{j}\right)$ is the number of expected admissions or deaths on the $j$ th day; $x_{j}(j=1, \ldots, p)$ correspond to the $p$ explanatory variables observed on the $\mathrm{jth}^{\text {th }}$ day (for instance, temperature, pollution) and $\beta_{\mathrm{j}}$ are the parameters one wishes to estimate and through which one should evaluate the effects of each explanatory variable on the expected number of admissions or deaths.

In order to obtain plausible results it is important to note that the association one wishes to characterize may be influenced by a series of factors which can confound or invalidate the results. These factors can include the presence of trends and seasonality, confounding variables (such as temperature and humidity), lags between cause and effect, and possible autocorrelation between observations measured over time and others (Pope III \& Schwartz, 1996; Schwartz et al., 1996). Concerning the possible existence of autocorrelation between observations recorded over time, the literature proposes statistical techniques to incorporate this characteristic, among which the Zeger model for counts series analysis (Zeger \& Liang, 1986).

The model should contain, as explanatory variables, the pollutant concentration, controls for seasonality (the usual approaches are the inclusion of indicator variables for months of the year or months of the study period, the use of sine and cosine terms or non-parametric functions, day of the week and holiday indicators), temperature, and humidity functions.

Models involving non-parametric functions, called generalized additive models, were proposed by Hastie \& Tibshirani (1990) and were recently adopted in the analysis of this type of data. These models proved highly useful not only to control seasonality and trends but also in modeling the relationship between morbidity and mortality markers and weather variables (temperature and humidity), which can be non-linear.

Concerning the lag between cause and effect, it is reasonable to consider that the effect of explanatory variables (temperature, humidity, pollution, etc.) on health indicators does not necessarily occur on the same day of the target event (admission or death). That is, the number of admissions or deaths on a given day can be a consequence of weather conditions and pollution on both the concurrent and previous days. A simple approach to examine the contribution of such factors over the course of several days is the utilization of models containing lags or moving averages for weather variables and pollutant concentrations. Models with different lags need to be investigated.

\section{Final remarks}

The studies performed by the LPAE are consistent with those of other researchers, despite having different pollutant concentrations, dispersion, and socioeconomic characteristics. The results support a consensus that air pollution is harmful to the public health, mainly for the groups considered susceptible, but also for the population at large. They also indicate that these effects occur even if pollutant concentrations are below the prevailing legal limits.

In the case of the city of São Paulo, where air pollution is closely linked to mobile sources, decreasing the impact on health demands an overhaul in the urban transportation design, including rational planning of the transportation system, research on alternative fuels, adoption of less pollutant technologies, and implementation of a public awareness program on air pollution's adverse effects.

In this context, epidemiological studies provide valuable tools to back the political and economic decision-making process in improving the environment. They are also useful for evaluating the real impact of restrictive measures al ready implemented in the city, such as the car scheduling program. 


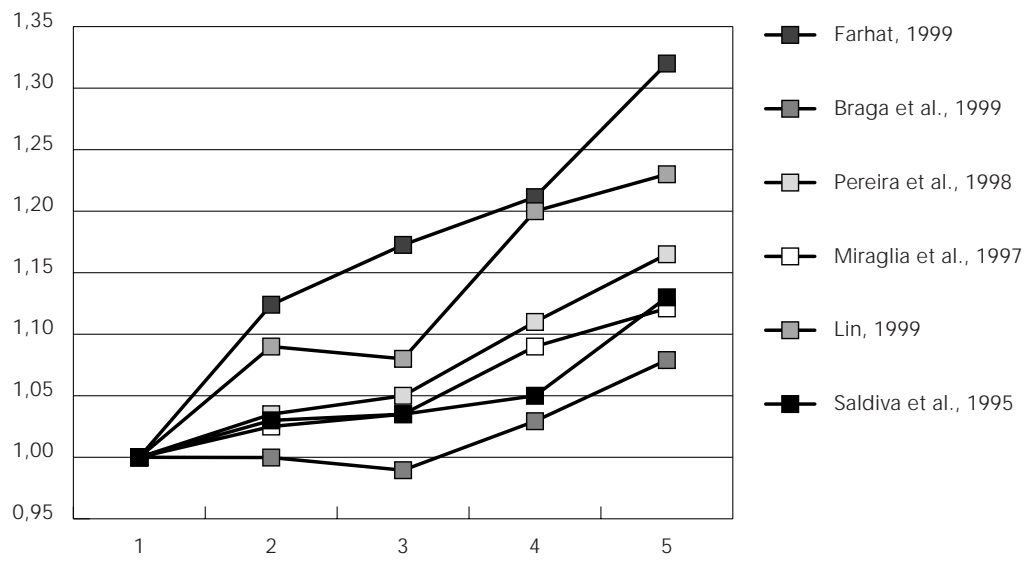

Figure 1 shows the result of our studies in terms of the relative risk for morbidity and mortality, considering five pollutant concentration categories for São Paulo city.

In short, the continuous enhancement of statistical tools allows us to increase the precision of our analyses, but this gain can only be effectively reflected in epidemiological research results if data quality is improved. Such data sources include:

- morbidity and mortality records;

- information from the environmental monitoring system;

- readily available records in the electronic media for immediate consultation.
All these will enable us to support relevant decision-making to establish acceptable emissions standards and pollution exposure limits, install an effective environmental system fostering the implementation of a valid environmental policy (with continuous development and improvement), and undertake sound management principles in the planning, implementation, control, and adjustment of measures with a view towards better results with lower costs and in a shorter time frame.

We aim to link the results of scientific knowledge to the needs of a society which seeks to improve its economic and social structures and achieve a sustainable development model that minimizes harm to both human beings and the environment.

\section{References}

BATALHA, J. R. F.; GUIM ARÃES, E. T.; LOBO, D. J. A.; LICHTENFELS, A. J. F. C.; DEUR, T.; CARVALHO, H.; ALVES, E. S.; DOMINGOS, M.; RODRIGUES, G. S. \& SALDIVA, P. H. N., 1999. Exploring the clastogenic effects of air pollutants in São Paulo (Brazil) using the Tradescantia micronuclei assay. Mutation Research, 426:229-232. 
BÖHM, G. M.; MASSAD, E.; SALDIVA, P. H. N.; GOUVEIA, M. A.; PASQUALUCCI, C. A. G.; CARDOSO, L. M. N.; CALDEIRA, M. P. R. \& CALHEIROS, D., 1983. Comparative toxicity of alcohol and gasoline fueled automobile exhaust fumes. In: Developments in the Science and Practice of Toxicology (A. W. Hayes, R. C. Scenell \& T. S. Miya, eds.), pp. 479-482, Amsterdam: Elsevier Science.

BÖHM, G. M.; SALDIVA, P. H. N.; PASQUALUCCI, C. A.; MASSAD, E.; MARTINS, M. A.; ZIN, W. A.; CARDOSO, W. V.; CRIADO, P. M. P.; KOM ATSUZAKI, M.; SAKAI, R. S.; NIGRI, E. M.; LEMOS, M.; CAPELOZZI, V. D.; CRESTANA, C. \& SILVA, R., 1989. Biological effects of air pollution in São Paulo and Cubatão. Environmental Research, 49:208-216.

BRAGA, A. L. F. B.; CONCEIÇÃO, G. M. S.; PEREIRA, L. A. A.; KISHI, H. S.; PEREIRA, J. C. R.; ANDRADE, M. F.; GONÇALVES, F. L. T.; SALDIVA, P. H. N. \& LATORRE, M. R. D. O., 1999. Air pollution and pediatric respiratory hospital admissions in São Paulo, Brazil. Journal of Environmental Medicine, 1:95-102.

CANTOR, K. P.; STEWART, P. A.; BRINTON, L. A. \& DOSEMECI, M., 1995. Occupational exposures and female breast cancer mortality in the United States. Journal of Occupational and Environmental Medicine, 37:336-348.

CETESB (Companhia de Tecnologia de Saneamento Ambiental), 1996. Air Quality Report in São Paulo State- 1995. São Paulo: CETESB.

CIOCCO, A. \& THOM PSON, D. J., 1961. A follow-up on Donora ten years after. Methodology and findings. American Journal of Public Health, 51:155-164.

DEVLIN, R. B.; MCKINNON, K. P.; NOAH, T.; BECKER, S. \& KOREN, H., 1994. Ozone-induced release of cytokines and fibronectin by alveolar macrophages and airway epithelial cells. American Journal of Physiology, 266:L612-619.

DOBSON, A. J., 1990. An Introduction to Generalized Linear Models. New York: Chapman \& Hall.

DOCKERY, D. W. \& POPE III, C. A., 1994. Acute respiratory effects of particulate air pollution. Annual Review of Public Health, 15:107-132.

DOCKERY, D. W.; POPE III, C. A.; XU, X.; SPENGLER, J. D.; WARE, J. H.; FAY, M. E.; FERRIS Jr., B. G. \& SPEIZER, F. E., 1993. An association between air pollution and mortality in six US cities. New England Journal of Medicine, 329:1753-1759.

ELSON, D. M., 1987. Atmospheric Pollution: Causes, Effects, and Control Policies. Oxford: Basil Blackwell Ltd.

FARHAT, S. C. L., 1999. Effects of Air Pollution in São Paulo City on Lower Respiratory Disease in a Pediatric Population. Tese de Doutorado, São Paulo: Faculdade de Medicina, Universidade de São Paulo.

FENSTER, F.; SWAN, S. H.; WINDHAN, G. C. \& NEUTRA, R. R., 1991. Assessment of reporting consistency in a case-control study of spontaneous abortion. American Journal of Epidemiology, 133: 477-488.

FEYCHTING, M.; SVENSSON, D. \& AHLBOM, A., 1998. Exposure to motor vehicle exhaust and childhood cancer. Scandinavian Journal of Work and Environmental Health, 24:8-11.

FIRKET, J., 1931. Sur les causes des accidents sur- venus dans la vallée de la Meuse, lors des brouillards de décembre 1930. Bulletin de l'Académie Royale de Médecine de Bel gique, 11:683-741.

FLETCHER, R. H.; FLETCHER, S. W. \&WAGNER, E. H., 1996. Epidemiologia Clínica: Elementos Essenciais. São Paulo: Artes Médicas.

GILM OUR, M. I. \& SELGRADE, M. K., 1993. A comparison of the pulmonary defenses against streptococcal infection in rats and mice following $\mathrm{O}_{3}$ exposure: Differences in disease susceptibility and neutrophil recruitment. Toxicology Applied Pharmacology, 123:211-218.

GRANT, W. F., 1998. Higher plant arrays for the detection of genotoxicity in air polluted environments. Ecosystem Health, 4:210-229.

HASTIE, T. \& TIBSHIRANI, R., 1990. Generalized Additive Models. London: Chapman \& Hall.

HATCH, G. E.; BOYKIN, E.; GRAHAM , J. A.; LEWTAS, J.; POTT, F.; LOUD, K. \& MU MFORD, J. S., 1985. Inhalable particles and pulmonary host defense: In vitro and in vivo effects of ambient air and combustion particles. Environmental Research, 36:67-80.

HILL, A. B., 1965. The environment and disease: Association or causation? Proceedings of the Royal Society of Medicine, 58:295-300.

KLEINBAUM, D. G.; KUPPER, L. L.; MULLER, K. E. \& NIZAM, A., 1998. Applied Regression Analysis and other Multivariable Methods. 3rd Ed. Duxbury: Pacific Grove.

LAGARD, F. \& PERSHAGEN, G., 1999. Parallel analyses of individual and ecologic data on residential radon, cofactors, and lung cancer in Sweden. American Journal of Epidemi ology, 149:268-274.

LEM OS, M.; LICHTENFELS, A. J. F. C.; AM ARO J r., E.; MACCHIONE, M.; MARTINS, M. A.; KING, M.; BÖHM, G. M. \& SALDIVA, P. H. N., 1994. Quantitative pathology of nasal passages in rats exposed to urban levels of air pollution. Environmental Research, 66:87-95.

LIN, C. A., 1999. Association between air pollution and respiratory illness in children in São Paulo, Brazil. Paedriatic and Perinatal Epidemiology, 13:475-488

LIOU, H. H.; TSAI, M. C.; CHEN, C. J.; JENG, J. S.; CHANG, Y. C.: CHEN, S. Y. \& CHEN, R. C., 1997. Environmental risk factors and Parkinson's disease: A case-control study in Taiwan. Neurology, 48:1583-1588.

LOGAN, W. P. D., 1953. Mortality in London fog incident, 1952. Lancet, 1:336-338.

MASSAD, E.; BÖHM, G. M. \& SALDIVA, P. H. N., 1993. Ethanol fuel toxicity. In: Handbook of Hazardous Materials (M. Corn, ed.), pp. 265-275, New York: Academic Press.

MASSAD, E.; SALDIVA, C. D.; CARDOSO, L. M. N.: SILVA, R.; SALDIVA, P. H. N. \& BÖHM, G. M.; 1985. Acute toxicity of gasoline and ethanol automobile engine exhaust gases: Comparative toxicity of engine fuel, ethanol exhaust fumes. Toxicol ogy Letters 26:187-192.

MASSAD, E.; SALDIVA, P. H. N.; SALDIVA, C. D.; CALDEIRA, M. P. R. \& BÖHM, G. M., 1986. Toxicity of prolonged exposure to ethanol and gasoline auto engine exhaust fumes. Environmental Research, 40:479-486. 
McCULLAGH, P. \& NELDER, J. A., 1989. Generalized Linear Models. 2nd Ed. London: Chapman \& Hall.

MIRAGLIA, S. G. E. K.; CONCEIÇÃO, G. M. S.; SALDIVA, P. H. N. \& STRAMBI, O., 1997. Analysis of the impact of fuel consumption on mortality rates in São Paulo. In: Urban Transport and the Environment for the 21st Century III (L. Sucharov \& G. Bidini, eds.), pp. 435-444, Southampton: Computational Mechanics Publication.

MORGENSTERN, H., 1995. Ecologic studies in epidemiology: Concepts, principles, and methods. Annual Reviews of Public Health, 16:61-81.

PEREIRA, L. A. A.; LOOMIS, D.; CONCEIÇÃO, G. M. S.; BRAGA, A. L. F.; ARCAS, R. M.; KISHI, H. S.; SINGER, J. M.; BÖHM, G. M. \& SALDIVA, P. H. N., 1998. Association between air pollution and intrauterine mortality in São Paulo, Brazil. Environment Health Perspectives, 106:325-329.

PEREIRA, P. M.; SALDIVA, P. H. N.; SAKAE, R. S.; BÖHM, G. M. \& MARTINS, M. A., 1995. Urban levels of air pollution increase lung responsiveness in rats. Environmental Research, 69:96-101.

POPE III, C. A., 1989. Respiratory diseases associated with community air pollution and a steel mill, Utah Valley. American Journal of Public Health, 79:623-628

POPE III, C. A. \& SCHWARTZ, J., 1996. Time series for the analysis of pulmonary health data. American Journal of Respiratory and Critical Care Medicine, 154:S229-233.

POPE III, C. A.; SCHWARTZ, J. \& RANSON, M. R. 1992. Daily mortality and PM 10 pollution in Utah Valley. Archives of Environmental Health, 47:211217

REYMÃO, M. S. F.; CURY, P. M.; LICHTENFELS, A. J. F. C.; BATTLEHNER, C. N.; CONCEIÇÃO, G. M. S.; CAPPELLOZI, V. L.; MONTES Jr., G. S.; M ARTINS, M. A.; BÖHM, G. M. \& SALDIVA, P. H. N., 1997. Urban air pollution enhances the formation of urethane-induced lung tumors in mice. Environmental Research, 74:150-158.

SADA-CIESLAR, M.; MAZUR, B.; BUSZMAN, Z. \& CIESLAR, G., 1994. Lead poisoning in children from the industrial region of Silesia: Markers of chronic intoxication. Wiad Lek, 47:601-607.

SALDIVA, P. H. N. \& BÖHM, G. M., 1998. Animal indicators of adverse effects associated with air polIution. Ecosystem Health, 4:230-235.
SALDIVA, P. H. N.; KING, M.; DELMONTE, V. L. C.; MACCHIONE, M.; PARADA, M. A. C.; DALIBERTO, M. L.; SAKAI, R. S.; CRIADO, P. M. P.; SILVEIRA, P. L. P.; ZIN, W. A. \& BÖHM, G. M., 1992. Respiratory alterations due to urban air pollution: An experimental study in rats. Environmental Research, 57:19-33.

SALDIVA, P. H. N.; LICHTENFELS, A. J. F. C.; PAIVA, P. S. O.; BARONE, I. A.; MARTINS, M. A.; MASSAD, E.; PEREIRA, J. C. R.; XAVIER, V. P.; SINGER, J. M. \& BÖHM, G. M., 1994. Association between air pollution and mortality due to respiratory diseases in children in São Paulo, Brazil: A preliminary report. Environmental Research, 65:218-225.

SALDIVA, P. H. N.; POPE III, C. A.; SCHWARTZ, J.; DOCKERY, D. W.; LICHTENFELS, A. J. F. C.; SALGE, J. M.; BARONE, I. \& BÖHM, G. M., 1995. Air pollution and mortality in elderly people: A time-series study in São Paulo, Brazil. Archives of Environmental Health, 50:159-163.

SCHWARTZ, J., 1994a. What are people dying of on high air pollution days? Environmental Research, 64:26-35.

SCHWARTZ, J. 1994b. Air pollution and daily mortality: A review and meta analysis. Environmental Research, 64:36-52.

SCHWARTZ, J.; SPIX, C.; TOULOUMI, G.; BACHÁROVÁ, L.; BARUMAMDZADEH, T.; Le TERTRE, A.; PIEKARKSI, T.; LEON, A. P.; PÖNKA, A.; ROSSI, G.; SAEZ, M. \& SCHOUTEN, J. P., 1996. Methodological issues in studies of air pollution and daily counts of deaths or hospital admissions. Journal of Epidemiology and Community Health, 50 (Sup. 1):S3-S11.

TAKAHASHI, K.; CASE, B. W.; DUFRESNE, A.; FRASER, R.; HIGASHI, T. \& SIEMIATYCKI, J., 1994. Relation between lung asbestos fiber burden and exposure indices based on job history. Occupational Environment on Medicine, 51:461-469.

WHO (World Health Organization), 1996a. Linkage Methods for Environment and Health Analysis. General Guidelines, HEADLAMP Project. Geneva, WHO.

WHO (World Health Organization), 1996b. Linkage Methods for Environment and Health Analysis. Technical Guidelines, HEADLAMP Project. Geneva, WHO.

ZEGER S. L., LIANG, K. Y., 1986. Longitudinal data analysis for discrete and continuous outcomes. Biometrics, 42:121-130. 